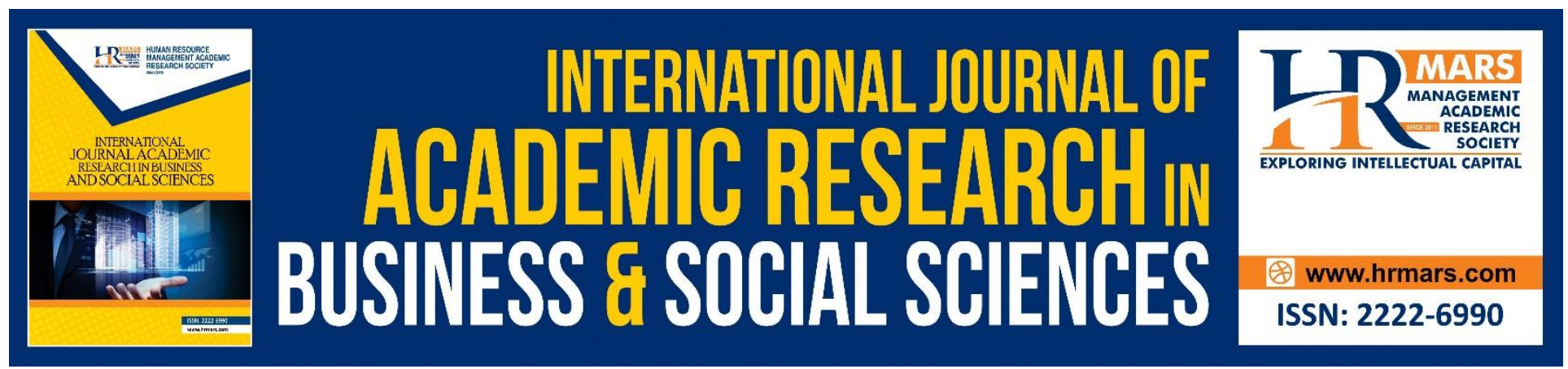

\title{
Identifying the Need for Developing the Preschool Teachers' Creativity Stimulation-Based Early Science Creative Teaching Model
}

Noazima Wahab, Zaharah Osman, Azli Ariffin

To Link this Article: http://dx.doi.org/10.6007/IJARBSS/v10-i7/7602

DOI:10.6007/IJARBSS/v10-i7/7602

Received: 03 May 2020, Revised: 05 June 2020, Accepted: 07 July 2020

Published Online: 29 July 2020

In-Text Citation: (Wahab et al., 2020)

To Cite this Article: Wahab, N., Osman, Z., \& Ariffin, A. (2020). Identifying the Need for Developing the Preschool Teachers' Creativity Stimulation-Based Early Science Creative Teaching Model. International Journal of Academic Research in Business and Social Sciences, 10(7), 751-760.

Copyright: (C) 2020 The Author(s)

Published by Human Resource Management Academic Research Society (www.hrmars.com)

This article is published under the Creative Commons Attribution (CC BY 4.0) license. Anyone may reproduce, distribute, translate and create derivative works of this article (for both commercial and non-commercial purposes), subject to full attribution to the original publication and authors. The full terms of this license may be seen at: $\underline{\text { http://creativecommons.org/licences/by/4.0/legalcode }}$

Vol. 10, No. 7, 2020, Pg. 751 - 760

http://hrmars.com/index.php/pages/detail/IJARBSS

JOURNAL HOMEPAGE

Full Terms \& Conditions of access and use can be found at http://hrmars.com/index.php/pages/detail/publication-ethics 


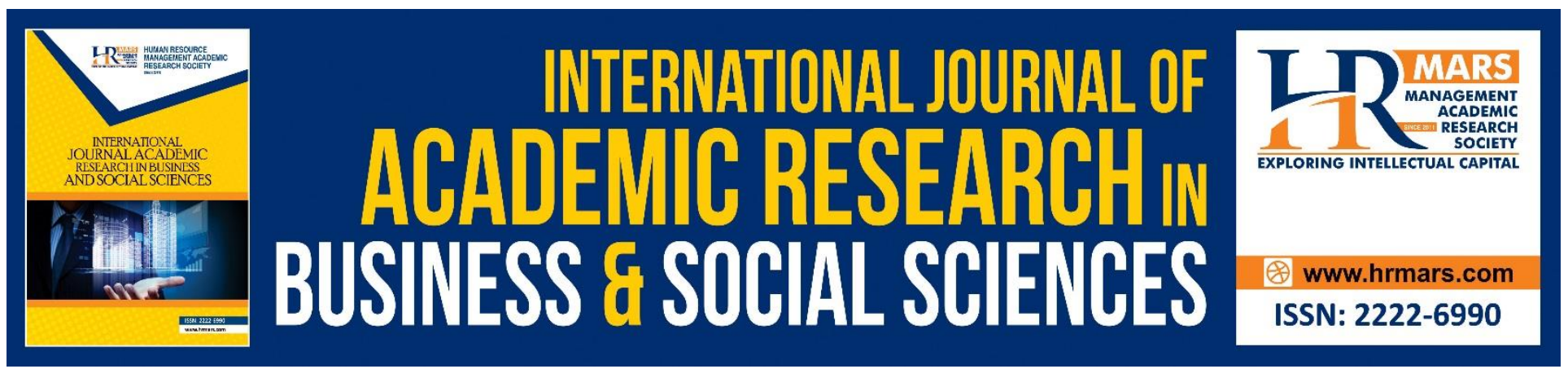

\title{
Identifying the Need for Developing the Preschool Teachers' Creativity Stimulation-Based Early Science Creative Teaching Model
}

\author{
Noazima Wahab, Zaharah Osman, Azli Ariffin \\ Faculty of Human Development, Universiti Pendidikan Sultan Idris, 35900 Tanjung Malim, Perak, \\ Malaysia
}

\begin{abstract}
This study aims to identify the views of the preschool teachers towards the need to construct the Early Science Creative Teaching Model Based on Preschool Teachers' Creativity Simulation. The Creative Teaching Theory by Torrance is used as a basic model in this study. The survey method used involves 100 preschool teachers with the aim of getting their perceptions about the need to construct this model. The data obtained was analysed using the Statistical Package for Social Science (SPSS) version 20.0. The data evaluation shows that the Cronbach Alpha value for this study is 0.898 . Meanwhile, the percentage of teachers who agree with the model construction is very high and the mean value for the construct creative teaching requirement is 4.5269 where the value obtained has reached a high level of requirement. From the finding of this study, it is clear that preschool teachers agree with this Early Science Creative Teaching Model Construction in Preschools.
\end{abstract}

Keywords: Creative Teaching, Creativity Stimulation, Early Science, Preschools, Need Analysis.

\section{Introduction}

A session of teaching is said to be creative when a teacher combines his or her existing knowledge and introduces a new process to instil the thought process to produce better results (Reilly, Lilly, Bramwell, \& Kronish, 2011). This process refers to the role of the teacher as an individual responsible in guiding the students in building the knowledge. This means that, creative teaching will be produced from teacher's ability to brainstorm ideas and a unique practice that can instil students' creative thinking by taking into account the aspects of originality, continuity, clarity and flexibility in teaching more meaningfully.

Literature studies show that creative teaching is also linked with teachers' creativity stimulation. Teachers' creativity stimulation is also teachers' way in encouraging creative practice among students. In line with it, in 2011, Curriculum Development Department (BPK) prepared a Creativiti Manual or Guidebook as a guideline for teachers to encourage their students to be systematically creative and innovative. The interaction between the teacher and students can influence the social, cognitive and creativity development that can determine students' readiness to 
go to school (Bierman et al., 2009). Other than that, if teachers have a positive attitude towards creativity when conducting classroom activities with the students, it will leave a positive impact towards one's motivation (Amabile, 1989; Clark \& Falls, 2017) achievement, creativity, selfconfidence and student's attitude towards the school (Rimm et al., 2018; Ihmeideh et al., 2010). Positive qualities and characteristics inherent in students will give a positive relationship towards their competency in the future. Other than that, students need to be taught to use the thinking skills creatively, ask questions that can help them to understand how and what needs to be learned during the teaching and learning process (Torrance, 1979).

Preschool teachers as the curriculum implementers play the role in the effort to instil and stimulate the creativity among preschool students. Creativity and innovation are demanded to produce a generation of students with the first-class thinking and compete in the $21^{\text {st }}$ century learning. Therefore, this effort has to be carried out at the early stage of schooling which is preschool level to implement the next stage of education. Creativity has to be instilled and taught in all core contained in the National Preschool Standard Curriculum (KSPK, 2017). This study will focus on the core of Early Science because it is seen to be very synonymous with high level of thinking so that teachers can help students to develop the creativity at an optimal level. Students are able to identify self-potential, self-tendency, tap the talent as future scientists, have high innovativeness and able to produce quality ideas and innovation.

Early Science Education in preschools can encourage students to obtain the knowledge about scientific facts, encourage their interest and curiosity, explore into the surroundings, observe, conduct experiments and make inferences. Other than that, Early Science education can create students' curiosity, concerning students' interest to try and carry out experiments at school or at home. Students are able to consolidate the social and emotional development where the science process can encourage interaction, work in groups and able to boost self-confidence. Students also learn to explore, discover new things and problem solution can be self-experienced in a fun learning (KSPK, 2017).

\section{Problem Statement}

Teachers play a pivotal role in transforming the education system by equipping themselves with knowledge so that they can increase their teaching quality and so that it can fulfil the learning quality other than fulfilling the aim and direction of the national education system (M.Zin et al., 2012) and yet, there are teachers who do not receive direct education be it from courses or training related to creative teaching ( $\operatorname{in} \& \mathrm{Wu}, 2016)$. There are also teachers who do not make the effort to improve the teaching quality to make it more creative (Ann, 2006).

The greatest challenge in the evolution of education in this country, is that there are still a lot of teachers at school who still practise traditional teaching which is teacher-centered, although they have been exposed and taught various current teaching strategies in teacher training (Abdullah \& Daud, 2018). This possibly happens due to the fact that teacher-centered teaching is the easiest and the most comfortable approach to use as it involves the most minimal preparation time. Other than that, teacher is more dominant than students who are naturally not creative demonstrated through obeyance and undivided acceptance to the teacher, and the fact that teacher can punish the students as a form of class discipline management (Beghetto \& Kaufman, 2014; Norsita \& Zainal, 2014) This will leave an impact to the students because Early Science education in preschools aims to develop a sense of enjoyment, excitement and curiosity of preschool students by exploring the world around 
them. (Cho et al., 2003). The teaching and learning process is a very important experience for students so that they can follow and understand the content of the lesson taught by the teacher.

The study from School Inspector and Quality Assurance (JKNK) from the year 2014-2017 finds that $25 \%$ of the teachers practise creative teaching and learning. From this study, only excellent teachers are involved in creative teaching (KPM, 2017). Based on this $25 \%$, there are still a great number of teachers who do not practise creative teaching in their lessons. Thus, preschool teachers must be the catalyst to an effective learning environment in creative teaching and they need to have adequate skills, knowledge and readiness to teach Early Science in preschools (Norliza, 2016). Thus, preschool teachers have to be ready to make a quality and creative teaching and learning implementation to build a solid foundation for preschool children (Halim, 2016)

To achieve the goal of learning, preschool teachers should always be ready to play the role so that students can learn something new about Early Science and they are guided in the right way (Rahim, 2005). A lot of preschool teachers are not brave to take the risks in doing experimental activities, not adapting teaching outside the method and still doing the same procedure every time they conduct an experiment in class. Thus, students' creativity will be limited as teachers' teaching will be too structured, students' ideas are neglected and students are too controlled during class activities (Hun et al., 2013)

Based on Jingbo \& Elicker (2005) done through an observation, it shows that $80 \%$ of teachers give a negative response when students produce their own ideas. This leaves an impact to the students in the teaching and learning session where they feel that they are not appreciated, there is no support from the teachers and they start to show the lack of interest to learn (Safiek, 2019).

Teachers teaching in preschools have different backgrounds such as experiences, skills, motivation, trust and worry. Teacher's attitude is one of the main factors in determining quality teaching. Among the main challenges is the factor of teacher's concern or worry in teaching science in preschools (Allif et al., 2017). This concern among teachers not only leaves an impact to the teaching quality but also affects the understanding on students' learning in the class (Yuruk, 2011). Other than that, the factor of teacher's concern leaves an impact towards preparing a dynamic and holistic learning environment (Norliza, 2016). If this happens, it wil leave a negative impact to students during the learning session as the teaching and learning process at preschool level is to create a sense of enjoyment, excitement and curiosity by way of exploring into the world around them (Eggen \& Kauchak, 2012). Preschool students feel that they are not able to practise the science process skills through investigation activities and this makes the students lack the interest to learn science in the next phase (Blank et al., 2014).

\section{Study Purpose}

This study aims to identify the level of requirement of developing the Early Science creative teaching model, based on preschool teachers' creativity stimulation from preschool teachers' perception. The objectives of this study are as follows:

a. Identify the level of requirement of developing the Early Science creative teaching model for the use of preschool teachers.

b. Identify the need for Early Science creative teaching for the use of preschool teachers.

\section{Study Questions}

This study will answer the following questions: 
a. Is there a need to develop the Early Science creative teaching model for preschool teachers' use?

b. What is the teachers' perception on the Early Science creative teaching requirement in preschools?

\section{Study Methodology}

A study analysis has been done on preschool teachers aiming to evaluate their needs in developing the creative teaching model. According to (Witkin, 1977), the needs analysis is the method used to identify the gao between the current situation and the target situation. Meanwhile (Usher \& McKillip, 2006) state that the needs analysis is an evaluative value for certain groups of people who have certain problems or issues to be solved. This study aims to see how preschool teachers adopt creative teaching in Early Science teaching. The needs analysis aims to probe into the existing issues and the requirement to develop the creative teaching model. The model designed can function as a practical guidance where it can help teachers to stimulate their creativity and increase students' creativity in the teaching of Early Science.

The needs analysis will be done through the survey method to identify the requirement of the creative teaching model based on teachers' opinions. The study participants were given a set of study questionnaire to get the feedback about the construction of the model. According to (M.Majid, 2004) the use of the questionnaires is more practical and effective when involving a large population. Researcher uses the questionnaire because it is easy to understand and it is unambiguous. Also, respondents find it easy to understand the purpose of the data collection. Additionally, the questionnaire has high validity and reliability.

This questionnaire is developed with references of past studies. However, it has been modified with the study background and question. The purpose of the questionnaire is to obtain data from the sample study. Meanwhile, according to (A.Muqsith et al., 2017), a questionnaire is used in studies because it can save time and it enables respondents to answer the questions in the questionnaire without a direct guidance and intervention from the researcher. The advantage of using a questionnaire is that if it is prepared well, it can produce consistent and trustworthy items (Cates, 1984).

According to (Marshall \& Gretchen Rossman, 2016) questionnaires that have strength in studies have the following characteristics such as (a) easy to manipulate and categorise the data for analysis, (b) manage and administer the data easily and effectively, also (c) easy to make generalisation.

\section{Study Sample}

The sampling method used is the convenience sampling. This method is appropriate with the study done based on the appropriateness and the convenience in getting the feedback from the participants of the study. This method is also suitable because the population in this study is uniform, encompassing MoE's preschool teachers. Thus, 100 preschool teachers were chosen at random all over the Peninsular to answer the questionnaire developed. The sample selection among the preschool teachers from MOE is those who are the implementers who teach in preschools. Thus, they are more knowledgeable about the requirements of preschools. 
INTERNATIONAL JOURNAL OF ACADEMIC RESEARCH IN BUSINESS AND SOCIAL SCIENCES Vol. 10, No. 7, July, 2020, E-ISSN: 2222-6990 @ 2020 HRMARS

\section{Study Data Analysis}

Data analysis is an important phase in a study. This is because the right use of a technique, and the data issued are very important. Researcher gathers all the quantitative data obtained from the questionnaire and analyses it using the SPSS program version 20.0. The analysis was done through the descriptive statistics. According to (M.Majid, 2004), descriptive statistics is the statistical method used to summarise, conclude, or present the data obtained so that it will give meaningful information. The descriptive analysis will be used to report the level of agreement of all of the preschool teachers about the items asked.

\section{Study Finding}

\section{Study Respondents' Demography}

The data distribution for the respondents is elaborated in Table 1, covering gender, age, academic, teaching experience and teaching location.

Table 1. Study Respondents' Demography

\begin{tabular}{|l|l|l|l|}
\hline \multicolumn{1}{|c|}{ Item } & \multicolumn{1}{|c|}{ Category } & Frequency & Percentage \\
\hline \multirow{4}{*}{ Gender } & Male & 17 & 17.0 \\
\cline { 2 - 4 } & Female & 83 & 83.0 \\
\hline \multirow{5}{*}{ Age } & $25-35$ years & 34 & 34.0 \\
\cline { 2 - 4 } & $36-45$ years & 46 & 46.0 \\
\cline { 2 - 4 } & 45 years and above & 20 & 20.0 \\
\hline \multirow{5}{*}{ Academic } & Diploma & 60 & 60.0 \\
\cline { 2 - 4 } & Bachelor Degree & 83 & 83.0 \\
\cline { 2 - 4 } experience & Master Degree & 11 & 11.0 \\
\hline \multirow{3}{*}{ School location } & $<5$ Years & 14 & 14.0 \\
\cline { 2 - 4 } & $6-10$ Years & 22 & 22.0 \\
\cline { 2 - 4 } & $>10$ Years & 64 & 64.0 \\
\cline { 2 - 4 } & City & 25 & 75.0 \\
\cline { 2 - 4 } & Rural areas & 75 & \\
\hline
\end{tabular}

Teacher distribution by gender lacks balance, where female teachers have higher percentage (83.0\%) compared to male teachers with only (17.0\%). The age of the respondent who answered these questions stayed at the highest range between the age of $36-45$ years ( $46.0 \%$ ) compared to 45 years and above (20.0\%). In terms of the respondents' academic achievement, teachers who have a degree are the highest population (83.0\%) whereas teachers with Master degree make the lowest population (11.0\%). If we look at the teaching experience, the highest percentage should be at a group more than 10 years (64.0\%) whereas the group with experience at least 5 years is the lowest group of respondents. All in all, (75.0\%) there are more respondents who teach preschools in rural areas compared to those teaching in the city.

Teachers' perception about the need to construct the Creative Teaching Model

The details of the study finding by item are shown in Table 2. 
INTERNATIONAL JOURNAL OF ACADEMIC RESEARCH IN BUSINESS AND SOCIAL SCIENCES Vol. 10, No. 7, July, 2020, E-ISSN: 2222-6990 @ 2020 HRMARS

Table 2. The need for the model construction

\begin{tabular}{|l|l|l|l|l|l|}
\hline NO & \multicolumn{1}{|c|}{ ITEM } & \multicolumn{1}{|c|}{ FREQUENCY } & \multicolumn{2}{|c|}{ PERCENTAGE } \\
\cline { 3 - 6 } \\
ITEM & \multicolumn{1}{|c|}{ YES } & NO & YES & \multicolumn{1}{|c|}{ NO } \\
\hline 1 & $\begin{array}{l}\text { Requiring a complete guidance for } \\
\text { preschool teachers' Early Science } \\
\text { Creative Teaching }\end{array}$ & 99 & 1 & 99.0 & 1.0 \\
\hline 2 & $\begin{array}{l}\text { Requiring the Early Science process skills } \\
\text { for creative teaching in preschools }\end{array}$ & 98 & 2 & 98.0 & 2.0 \\
\hline 3 & $\begin{array}{l}\text { Requiring extensive guidance on the } \\
\text { steps of Early Science process skills to } \\
\text { increase students' creativity. }\end{array}$ & 96 & 4 & 96.0 & 4.0 \\
\hline 4 & $\begin{array}{l}\text { Requiring a model of Early Science } \\
\text { creative teaching to stimulate teachers' } \\
\text { creativity and enhance students' } \\
\text { creativity. }\end{array}$ & 28 & 2 & 98.0 & 2.0 \\
\hline
\end{tabular}

Table 2 provide the findings for Section B concerning the need for the construction of Early Science creative teaching model whereby all the respondents chose to strongly agree with the need for the model construction.

\section{Teachers' Perception Towards the Teaching of Early Science Creative Teaching in Preschools} The study findings on teachers' perception towards Early Science creative teaching in preschools can be found in Table 3.

Table 3: Teachers' perception on Early Science Creative Teaching in preschools

\begin{tabular}{|c|c|c|c|}
\hline No. & Statement & Mean & $\begin{array}{l}\text { Standard } \\
\text { Deviation }\end{array}$ \\
\hline 1 & $\begin{array}{l}\text { I agree that there should be a guideline related to } \\
\text { creative teaching planning for Early Science in } \\
\text { preschools }\end{array}$ & 4.5100 & 0.73161 \\
\hline 2 & $\begin{array}{l}\text { I agree that the creative teaching approach needs to } \\
\text { adopt an appropriate teaching model. }\end{array}$ & 4.4800 & 0.71746 \\
\hline 3 & $\begin{array}{l}\text { I agree that that there should be an Early Science } \\
\text { creative teaching model developed, that is appropriate } \\
\text { to help stimulate teachers' creativity. }\end{array}$ & 4.4500 & 0.78335 \\
\hline 4 & $\begin{array}{l}\text { I agree that there shoud be an Early Science creative } \\
\text { teaching model that is appropriate to help expand } \\
\text { students' creativity. }\end{array}$ & 4.4900 & 0.73161 \\
\hline 5 & $\begin{array}{l}\text { I agree that there has to be guidance in implementing } \\
\text { creative teaching in Early Science activities in } \\
\text { preschools }\end{array}$ & 4.4000 & 0.76541 \\
\hline 6 & $\begin{array}{l}\text { I agree that the ability to feed the curiosity can increase } \\
\text { students' creativity in Early Science activities }\end{array}$ & 4.6200 & 0.56461 \\
\hline
\end{tabular}


INTERNATIONAL JOURNAL OF ACADEMIC RESEARCH IN BUSINESS AND SOCIAL SCIENCES Vol. 10, No. 7, July, 2020, E-ISSN: 2222-6990 @ 2020 HRMARS

\begin{tabular}{|l|l|l|l|}
\hline $\mathbf{7}$ & $\begin{array}{l}\text { I } \text { agree that the ability to observe can increase } \\
\text { students' creativity in Early Science activities }\end{array}$ & 4.6300 & 0.54411 \\
\hline $\mathbf{8}$ & $\begin{array}{l}\text { I agree that the ability to explore can increase students' } \\
\text { creativity in Early Science activities }\end{array}$ & 4.6300 & 0.56237 \\
\hline $\mathbf{9}$ & $\begin{array}{l}\text { I agree that the ability to predict can increase students' } \\
\text { creativity in Early Science activities }\end{array}$ & 4.5400 & 0.61002 \\
\hline $\mathbf{1 0}$ & $\begin{array}{l}\text { I agree that the ability to classify can increase students' } \\
\text { creativity in Early Science activities }\end{array}$ & 4.5600 & 0.59152 \\
\hline $\mathbf{1 1}$ & $\begin{array}{l}\text { I agree that the ability to make inferences can increase } \\
\text { students' creativity in Early Science activities. }\end{array}$ & $\mathbf{4} .5500$ & 0.57516 \\
\hline $\mathbf{1 2}$ & $\begin{array}{l}\text { I agree that communicative ability can enhance } \\
\text { students' creativity in Early Science activities }\end{array}$ & 4.5200 & 0.64322 \\
\hline $\mathbf{1 3}$ & $\begin{array}{l}\text { I agree that there should be courses related to creative } \\
\text { teaching dalam Early Science di preschools }\end{array}$ & 4.4500 & 0.78335 \\
\hline
\end{tabular}

Table 3 discusses teachers' perception on Early Science creative teaching based on the creativity stimulation of preschool teachers. Based on the analysis, it is found that item 8 which is "I agree that the ability to explore can increase students' creativity in Early Science activities" $(M=4.63)$ and item 9 which is "I agree that the ability to predict can increase students' creativity in Early Science activities" $(M=4.63)$ are at high level. This means that teachers agree that the science process skills are needed to enhance students' creativity in Early Science activities. However, for item 5 which is "I agree that there has to be guidance in implementing creative teaching in Early Science activities in preschools" obtained the lowest mean which is $M=4.40$. This finding shows that teachers did not really agree to receive guidance in carrying out Early Science creative teaching. Conclusively, teachers agree that creativity stimulation is needed in Early Science creative teaching in preschools.

\section{Conclusion}

Based on the finding from the needs analysis, there is a need for the construction of a creative teaching model as a choice in Early Science Education. Based on the study objective determined earlier on, findings show that there is also a need for guidance, guideline and process in facilitating preschool teachers to instil creative teaching in the teaching of Early Science in preschools. Thus, it can be concluded that teachers strongly agree that the construction of the Preschool Teachers' Creativity Stimulation-Oriented Early Science Creative Teaching Model needs to be carried out.

Next, the finding of this study has also shown the level of agreement of the teachers with regard to the elements of creative teaching and creativity stimulation that need to be included in the model. To answer this question, about 17 items concerning the elements of creative teaching and creativity stimulation have been proposed based on the literature review. All in all, teachers agree that all the items have served as the guideline to the construction of the model. Therefore, based on the finding of this study, the model of early science creative teaching based on creativity stimulation for preschool teachers needs to be developed. 
INTERNATIONAL JOURNAL OF ACADEMIC RESEARCH IN BUSINESS AND SOCIAL SCIENCES

Vol. 10, No. 7, July, 2020, E-ISSN: 2222-6990 @ 2020 HRMARS

\section{Corresponding Author}

Zaharah binti Osman

Senior Lecture

Early Childhood Education Department, Faculty of Human Development, Sultan Idris Education University

Email: zaharah@fpm.upsi.edu.my

\section{References}

Halim, M. (2016). Amalan Pedagogi Guru Prasekolah Permulaan. https://doi.org/10.13140/RG.2.2.14328.65287

Muqsith, A., Zaharah, H., Maisarah, A. M., Farazila, Y., \& Ridhuan, M. J. (2017). Masalah Etika Dan Akhlak Pelajar Kemahiran Kejuruteraan Analisis Keperluan. JuKu - Jurnal Kurikulum \& Pengajaran Asia Pasifik, 5(2), 34-45.

Rahim, A. R. (2005). Profesional Keguruan: Prospek dan cabaran. Dewan Bahasa dan Pustaka.

Amabile, T. M. (1989). Growing up creative: Nurturing a lifetime of creativity. Crown House Publishing Limited.

Rimm, S., Siegle, D. B., \& Davis, G. A. (2018). Education of the gifted and talented (7 th). Pearson.

Beghetto, R. A., \& Kaufman, J. C. (2014). Classroom contexts for creativity. High Ability Studies, 25(1), 53-69. https://doi.org/10.1080/13598139.2014.905247

Bierman, K., Domitrovich, C., \& Darling, H. (2009). Early Prevention Initiatives. In J. Roopnarine \& J. Johnson (Eds.) Approaches to Early Childhood Education, 5th Ed. Pearson Merrill Prentice Hall.

Blank, J., Damjanovic, V., Silva, A., \& Weber, S. (2014). Authenticity and "Standing Out:" Situating the Project Approach in Contemporary Early Schooling. Early Childhood Education Journal, 42. https://doi.org/10.1007/s10643-012-0549-2

Cates, W. M. (1984). A practival guide to educational research. Pearson College Div.

Cho, H., Kim, J., \& Choi, D. H. (2003). Early Childhood Teachers' Attitudes toward Science Teaching: A Scale Validation Study. Educational Research Quarterly, 27(2), 33.

Clark, K. R., \& Falls, W. (2017). Tuning contact transport mechanisms in high on / off ratio bilayer MoSe 2 transistors. L.D.N Mouafo, F. Godel, G. Froehlicher, S. Berciaud, B. Doudin, M. V. Kamalakar, J-F. Dayen, 2D Materials, 4, 015037. https://doi.org/3592584

Eggen, P. D., \& Kauchak, D. P. (2012). Educational Psychology: Windows On Classroom (9th ed.). Pearson.

Ihmeideh, F. M., Al-Omari, A. A., \& Al-Dababneh, K. A. (2010). Attitudes toward communication skills among Students'-Teachers' in Jordanian Public Universities. Australian Journal of Teacher Education, 35(4), 1-11. https://doi.org/10.14221/ajte.2010v35n4.1

Jingbo, L., \& Elicker, J. (2005). Teacher?Child Interaction in Chinese Kindergartens: An Observational Analysis. International Journal of Early Years Education, 13(2), 129-143.

Hun, J. L., Abdullah, F. A. P., \& Hadi, M. A. B. (2013). Aplikasi Konsep Fizik Dalam Menyelesaikan Masalah Yang Berasaskan STEM Bagi Pelajar Tingkatan Enam Atas. 2nd International Seminar on Quality and Affordable Education, Isqae, 470-481. https://doi.org/10.1016/j.msea.2007.05.109

KSPK. (2017). Kurikulum Standard Prasekolah Kebangsaan. In BPK, KPM. Kementeriaan Pendidikan Malaysia.

Ann, L. M. (2006). On Creativity: Awakening the Creative Mind. Pelanduk Publications.

Lin, C. S., \& Wu, R. Y. W. (2016). Effects of Web-Based creative thinking teaching on students' 
INTERNATIONAL JOURNAL OF ACADEMIC RESEARCH IN BUSINESS AND SOCIAL SCIENCES

Vol. 10, No. 7, July, 2020, E-ISSN: 2222-6990 @ 2020 HRMARS

creativity and learning outcome. Eurasia Journal of Mathematics, Science and Technology Education, 12(6), 1675-1684. https://doi.org/10.12973/eurasia.2016.1558a

Majid, M. K. (2004). Kaedah penyelidikan pendidikan. Dewan Bahasa dan Pustaka.

Marshall, C., \& Rossman, G. (2016). designing qualitative research (6th ed.). Sage Publication Ltd.

Norliza, A. (2016). Pemahaman Guru Prasekolah Tentang konsep belajar melalui bermain dan cara kanak-kanak belajar di prasekolah. (U. Penerbit Fakulti Pendidikan (ed.)).

Norsita, A., \& Zainal, M. (2014). Tinjauan awal interaksi guru-guru -kanak-kanak dalam pemupukah pemikiran kreatif kanak-kanak prasekolah. Proceeding of the Social Sciences Research ICSSR, 910 June 2014, 735-746.

Reilly, R. C., Lilly, F., Bramwell, G., \& Kronish, N. (2011). A synthesis of research concerning creative teachers in a Canadian context. Teaching and Teacher Education, 27(3), 533-542. https://doi.org/10.1016/j.tate.2010.10.007

Safiek, M. (2019). Pemupukan Kreativiti Kanak-Kanak : Kajian Kes Amalan. Malaysian Online Journal of Education, 3(1), 34-48.

Sale, D. (2005). De-mystifying Creative Teaching Competence. Paper Presented at the International Conference on Redesigning Pedagogy: Research, Policy, Practice Held at National Institute of Education, Nanyang Technological University, 1-9.

Torrance, E. P. (1979). The search for satori and creativity. Creative Education Foundation Inc.

Usher, C. L., \& McKillip, J. (2006). Need Analysis: Tools for the Human Services and Education. Contemporary Sociology, 17(3), 369. https://doi.org/10.2307/2069663

Witkin, B. R. (1977). Needs Assessment Kits, Models and Tools. Educational Technology, 17(11), pp518.

Abdullah, R. I., \& Daud, I. (2018). Dalam Kalangan Guru Pelatih Pengajian Agama Institut Pendidikan Guru Kampus Dato' Razali Ismail. Asian People Journal, 1, 45-65.

Yuruk, N. (2011). The Predictors of Pre- Service Elementary Teachers ' Anxiety About Teaching Science. Journal of Baltic Science Education, 10(1), 17-26. 